\title{
BIOTEHNOLOGII FARMACEUTICE MODERNE IN VITRO APLICATE ÎN MEDICINĂ
}

\author{
Calalb Tatiana \\ Universitatea de Stat de Medicină și Farmacie "Nicolae Testemițanu”, Chișinău, Republica Moldova \\ e-mail: tatiana.calalb@usmf.md
}

Astăzi suntem martorii și beneficiarii aplicării în producere a rezultatelor cercetărilor fundamentale și experimentale biotehnologice in vitro în diverse laboratoare știinţifice ale lumii, care au evoluat într-un nou domeniu - bioindustrie aplicată. Biotehnologiile in vitro, asociate cu progresele cercetărilor moderne, în secolul XXI au devenit adevărate bioindustrii, fiind parte componentă a economiei multor țări avansate. Conform datelor statistice, domeniile de aplicare a biotehnologiilor in vitro sunt: sănătate (farmacie, medicină, cosmetică) - 51\%, nutriție umană și animalieră - $14 \%$, agricultură $-12 \%$, ecologie și energie câte $-6 \%$, alte domenii $-11 \%$.

Companii biotehnologice pe glob cu linii industriale active în anul 2010 erau cca $5000 \mathrm{cu}$ următoarea distribuție: în Europa - 2185, America - 1880, Asia - 750, Australia - 185. Majoritatea companiilor biotehnologice investesc în cercetări biotehnologice fundamentale și aplicative mai mult de jumatate din venitul obținut. Renumite companii biofarmaceutice in vitro în SUA sunt: Amgen (cea mai mare după numarul colaboratorilor, veniturilor şi liniilor de producere cu spectru larg de produse biotehnologice), Genentech, Genzyme și Biogen. Veniturile și bioprodusele la 2 grupuri biotehnologice (San Diego-La Jolla și Bay Area) din California constituie a parta parte a celor din SUA. Cele mai renumite companii biotehnologice în Europa sunt: Seronto (Elveția) - recunoscută în producerea hormonilor, enzimelor, anticorpilor pentru domeniu endocrinologic, imunologic și soluționarea problemelor infertilității; filiala Seronto din Spania - producator global al hormonului de creștere; Oryzont Genomics din Barselona - medicamente pentru Parkinson și Alzheimer; Biotech GPS (Germania) - lider biotehnologic în Europa cu 400 filiale; Celltech (Marea Britanie) - produce $40 \%$ din produsele biotehnologice pentru medicină; Sang Stat, Drug Abuse Science și Eurofins (Franţa) lucrează cca 40 ani cu mai mult de 300 de filiale în domeniul medicinei, cosmeticii şi alimentației. Companii biotehnologice nipone cu aplicare în medicină: Fujitsu's Biotechnology Division (cercetări ale genelor implicate în cancer, procese inflamatorii, hipertensiune), Japan Bioindustry Association (JBA) - dislocată în 3 regiuni biotehnologice (Kanto, include și Tokyo - a 3 parte din tot venitul national, Kinki/Kansai și Hokkaido) produc biofarmaceutice pentru diagnostic (94), biofarmaceutice ca proteine, secvente de AND etc. (78) bioinformatice (41) și consumabile (38). Proiectul Millenium lansat în Japonia (anul 2000) cu 3 direcții de cercetare (Genetica orezului; Genetica umană și medicina regenerativă; Iniţierea centrului de analiză a infromației obținute în cercetarea biologică și elaborarea liniilor de producere industrială) a avut obiectivele: studiul genelor pentru tratarea cancerului, demenței, diabetului și hipertensiunii; producerea secvențelor de ADN, producerea biopreparatelor prin microorganisme cu genomul ameliorat. În Australia companiile biotehnologice: Arch Oncology - producătoare de biomedicale și Ernst\&Young - cu 67\% din biotehnologiile in vitro a regiunii Asia-Pacific.

În farmacie apare o generație nouă de medicamente, produse via in vitro în baza E.coli cu genomul modificat genetic sau recombinant. Astfel, apare insulina umană via in vitro sub diferite denumiri comerciale la nivel global: Lantus, produs de Novo Nordisk (Danemarca) și - Bioton (Polonia); Humulong - Sanofi (Franța) și Wockhardt (India); Januvia - Eli Lily (SUA). Prima producție industrială in vitro a hormonului creșterii somatotropina a fost în 1979, firma Genentech (California), iar astăzi 59\% produce SUA, 23\% - Europa, 10\% - Asia. Hormonul eritropoietina a fost produs I dată de Epogen (SUA) în anul 1989. Interferonul gama uman in vitro a fost lansat în anul 1982 de firma CellGenix (Germania). Deceniile secolului XXI au fost marcate prin generaţia nouă de medicamente în terapia cancerului: Nartograstim (Sanofi, Franța), Leucentis (Novartis, Suedia), Neulasta (Eli Lily, SUA), Endostatin (Amgen, SUA). Astăzi biotehnologiile moderne in vitro reprezintă o parte componentă în obținerea produselor inovatoare, eficiente, rentabile și cu noi însuşiri, iar, în viitorul apropiat vor constitui componentul de bază al industriilor farmaceutice, alimentare şi cosmetice. 